\title{
Study of Open Spaces in the Context of Dhaka City for Sustainable Use: A Syntactic Approach
}

\author{
Matluba Khan
}

\begin{abstract}
Open spaces are one of the major elements of urban spaces. These are essential for the purpose of different public functions, recreational and leisure activities of the urban dwellers. Lack of open spaces is detrimental to urban life. In rapidly urbanizing countries open spaces are shrinking at an alarming rate and becoming less accessible. In Dhaka it is found that a number of large and medium scale open spaces are scattered in the city. But often these open spaces are not used to their full potential. One of the reasons is the location of the open space and its accessibility. The physical location of these spaces determines to a large instant whether they will be frequently used or not. This paper aims to the study of the open spaces in the context of Dhaka city, their potentialities and in some cases the reason of failure to work as a potential urban open space using space syntax.
\end{abstract}

Index Terms-Accessibility, Dhaka City, location, open space, Space syntax, spatial structure, urbanity.

\section{INTRODUCTION}

Open spaces are the lungs of a city or a town. They are used by the city people in different time for different purposes. In cities of developing countries green open spaces are needed for environmental and ecological balance. The large scale open spaces are used by the middle income urbanity for recreational purpose. Such areas are often found to be misused by anti-social occurrences, thereby resulting into dehumanized areas (Nilufar 1999). There are lots of factors that have impact on the potential use of these open spaces and also on the failure of some. This paper only deals with the physical location and accessibility of these open spaces using the space syntax program.

The urban population of Dhaka suffers from lack of proper urban facilities. The role of public open spaces both at community and city level, is important to improve the social ties and control for future generations. As a result 'presence of' and 'accessibility to' urban open spaces is emphasized in different phases of urban design. Through the use of Space syntax ${ }^{2}$, the accessibility of these spaces will be studied. The paper aims to find out whether there prevails any relationship between open space and spatial structure of the city. And by combining it with the policies for these open spaces this study thrives to find out some strategic guidelines for the utmost use of them.

Manuscript received June 30, 2013; revised August 7, 2013. The space syntax method is developed by the Unit for Advanced Architectural Studies, Bartlett School of Architecture, University College London, London.

M. K. is with the Department of Architecture, Bangladesh University of Engineering and Technology (BUET), Dhaka-1000 (e-mail: matluba.khan@gmail.com).

\section{OBJECTIVE OF THE STUDY}

The main purpose of this paper is to study the existing open spaces and analyze them with space syntax in order to assess the reason behind their use by the urbanity in Dhaka.

The objectives of the research are, therefore, as follow- 1) to locate and identify the large public open spaces in Dhaka city. 2) to analyze the accessibility and location of these open spaces using space syntax 3) to find out whether there lies any relationship between the reasons of the use of these open spaces with the spatial structure of the city and 4) to suggest some implementation strategy for the potential use of them.

\section{SCOPE OF THE STUDY}

The present study only focuses on the large scale open spaces of Dhaka city within its limited scope.

\section{Methods of the Research}

Based on review of literature some criteria for successful open spaces have been tried to be established. Six large open spaces selected based on physical size are then analyzed using space syntax. The findings of the syntactic analysis are triangulated with some observations from literature which led to some implementation strategies.

\section{LITERATURE REVIEW}

\section{A. Definition and Importance of Open Space}

Open space includes all private and public land that are open in character and used as a place for open air recreation that may include from a small play lot to vast hunting grounds. This consists of all 'wanderable' land like college campuses, or agricultural areas. (Nabi 1978)

Open spaces are those that are open in character, accessible to all, which facilitate meeting of groups of people and are used for recreation purpose.

According to Nilufar (1999), there are basically three functions which open spaces serve-

1) It can meet positive human needs- both physically and psychologically- in recreation amenities.

2) It can enhance and protect the resource base- the air, water, soil, plants and in turn the animals.

3) It can effect economic development decision like tourism, development patterns, employment, real estate values etc. 


\section{B. Classification of Open Spaces}

It is noted that open spaces are classified in different ways for different countries by different authors.

According to Nabi (1978), open spaces can generally be classified into two broad categories according to their use pattern- a)for active recreation such as play lot, play field, playground, sports ground, stadium etc. b) for passive recreation such as gardens, parks, parkways, greenbelts etc.

Considering the nature of the land and the type of open space use, Nilufar (1999) ordered all the public open spaces within Dhaka City under the following four categories.

TABLE I: Open SPACE HierarChy FOR THE City OF DHAKa SUgGESTED

\begin{tabular}{|c|c|c|c|}
\hline $\begin{array}{l}\text { Type of Open } \\
\text { space }\end{array}$ & Criteria & Example & Area \\
\hline Urban parks & Large open spaces & $\begin{array}{l}\text { Ramna park, } \\
\text { Chandrima udyan, } \\
\text { Osmani udyan, } \\
\text { Sohrawardy udyan }\end{array}$ & $\begin{array}{l}50-80 \\
\text { acres }\end{array}$ \\
\hline $\begin{array}{l}\text { Urban } \\
\text { recreational } \\
\text { areas }\end{array}$ & $\begin{array}{l}\text { Open spaces } \\
\text { developed and } \\
\text { assigned for more or } \\
\text { less organized } \\
\text { outdoor recreational } \\
\text { activities }\end{array}$ & $\begin{array}{l}\text { Stadiums and tennis } \\
\text { Complex at } \\
\text { metropolitan scale } \\
\text { Armanitola play field } \\
\text { at locale scale }\end{array}$ & $\begin{array}{l}2-9 \\
\text { acres }\end{array}$ \\
\hline $\begin{array}{l}\text { Urban } \\
\text { development } \\
\text { open spaces }\end{array}$ & $\begin{array}{l}\text { Urban plazas/parks of } \\
\text { various size in } \\
\text { commercial and } \\
\text { institutional areas }\end{array}$ & $\begin{array}{l}\text { Pantha kunja, } \\
\text { Anowara udyan, } \\
\text { Gulistan park }\end{array}$ & $\begin{array}{l}2-8 \\
\text { acres }\end{array}$ \\
\hline $\begin{array}{l}\text { Functional } \\
\text { open spaces }\end{array}$ & Functional in nature & $\begin{array}{l}\text { Azimpur Graveyard, } \\
\text { Islambagh Eidgah } \\
\text { Math }\end{array}$ & \\
\hline
\end{tabular}

\section{Criteria of a good public open space}

Mark Francis, (2003) in his book named Urban Open Spaces-designing for User Needs, has narrated some criteria for a good public open space.

TABLE II: CRITERIA OF A GOOD PUBLIC OPEN SPACE

\begin{tabular}{|c|l|l|}
\hline Ingredients & Criteria & Measure \\
\hline \multirow{5}{*}{ Accessibility } & $\begin{array}{l}\text { Linkages } \\
\text { Walk ability } \\
\text { Connectedness } \\
\text { Convenience }\end{array}$ & $\begin{array}{l}\text { Behavior } \\
\text { Mapping of use } \\
\text { Pedestrian activity } \\
\text { Traffic data }\end{array}$ \\
\hline \multirow{3}{*}{ Comfort } & $\begin{array}{l}\text { Uses } \\
\text { Celebration } \\
\text { Usefulness } \\
\text { Sustainability }\end{array}$ & $\begin{array}{l}\text { Property values } \\
\text { Changes in land use } \\
\text { Retail sales }\end{array}$ \\
\hline \multirow{5}{*}{ Sociability } & $\begin{array}{l}\text { Safety } \\
\text { Good places to sit } \\
\text { Attractiveness } \\
\text { Cleanliness }\end{array}$ & $\begin{array}{l}\text { Crime statistics } \\
\text { Building conditions } \\
\text { Environmental data }\end{array}$ \\
& $\begin{array}{l}\text { Friendliness } \\
\text { Interactivity } \\
\text { diversity }\end{array}$ & $\begin{array}{l}\text { Studies of street use } \\
\text { Diversity of users } \\
\text { Social networks }\end{array}$ \\
\hline
\end{tabular}

Among all these, this study only focuses on the issue of accessibility or permeability. This research only deals with the location and physical entrance to the open spaces.

\section{Reasons of Failure of an Urban Space}

The responsiveness of any environment depends on its accessibility, variety, legibility, robustness, visual appropriateness, richness and personalization (Bentley, Alcock, Murrain, McGlynn, Smith, 1985). The absence of these qualities might result in failure of that space as a responsive one.

Mark Francis (2003) identified some reasons for why public spaces fail from which the following table is derived.

TABLE III: REASONS OF FAILURE OF AN OPEN SPACE

\begin{tabular}{|l|l|}
\hline \multicolumn{1}{|c|}{ External features } & \multicolumn{1}{c|}{ Internal features } \\
\hline Inaccessible spaces & Lack of good places to sit \\
\hline Poor entrances & Lack of gathering points \\
\hline Domination of a place by vehicles & Dysfunctional features \\
\hline $\begin{array}{l}\text { Blank walls or dead zones around } \\
\text { the edges of a place }\end{array}$ & $\begin{array}{l}\text { Paths that don't go where people } \\
\text { don't want to go }\end{array}$ \\
\hline & Inconveniently located transit stops \\
\hline
\end{tabular}

\section{Public Open SPACES OF DHAKa CiTY}

Once Dhaka was called the 'Venice of the Orient' because of its large open spaces with the lushness of nature. During British period Dhaka experienced a northward expansion while the peripheral green areas were incorporated within the city boundary. A green kernel was kept open at the center of the town. The Ramna Park was established in 1908 and the Sohrawardy Uddyan in 1972 with huge plantation. With the rapid urbanization, the amount of open spaces is decreasing gradually. Lack of consciousness, initiative and most of all insensitivity of both public and private sectors towards ecology, environment and sociological factors have led to- 1. Rapid decline of open spaces and waterbodies and 2. Increasing loss of accessibility to the open spaces and water bodies. In these days it is suggested to keep $25 \%$ land of an ideal city as open (Nilufar 1999). Here in old Dhaka only 5\% and in new Dhaka $12 \%$ of land is green and open (DMDP 1995). However Dhaka Structure Plan urges to have $20 \%$ of open spaces in Dhaka for its future generation (DMDP 1995). At present it is imperative to identify the requirement and the potential open spaces for future generation.

The open spaces scattered at different parts of the city cannot be brought under concrete division. This paper only focuses on the physically large and well-known public open spaces of Dhaka city. Six distinctive open spaces are identified for this study (Fig. 1). These open spaces are-

TABLE IV: List OF PUBlic OPEN SPACES Which THIS PAPER STUDIES.

\begin{tabular}{|c|c|c|}
\hline & Name of the Open Space & Area (acre) \\
\hline 1 & Sohrawardy Udyan & 55 \\
\hline 2 & Ramna Park & 58 \\
\hline 3 & $\begin{array}{c}\text { North and South Plaza of National } \\
\text { Assembly Building }\end{array}$ & 95 \\
\hline 4 & Chandrima Udyan & 77 \\
\hline 5 & National Parade Square & 120 \\
\hline 6 & Botanical Garden & \\
\hline
\end{tabular}




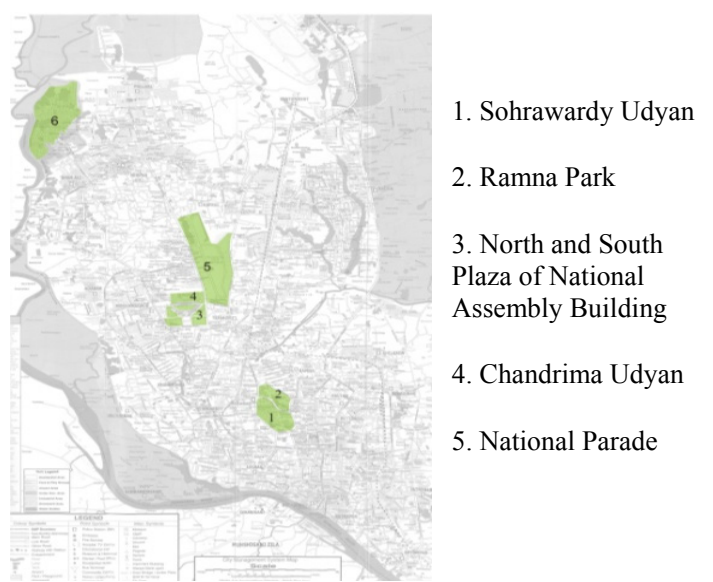

Fig. 1. Map (RAJUK 2007) showing large scale and well-known open spaces in Dhaka City

\section{SPATIAL ANALYSIS}

Space Syntax is a method for describing and analyzing the relationships between social structure and spatial structure. The analysis of the urban grids is based on the axial map. Every island or urban block is surrounded by axial lines and every street intersection within the urban grid is recorded as an intersection of axial lines. Thus the axial structure might be considered as an objective transcription of the structure of the urban grid. There are four first orders and these four may in turn be correlated to form second order measures (Fig. 2).

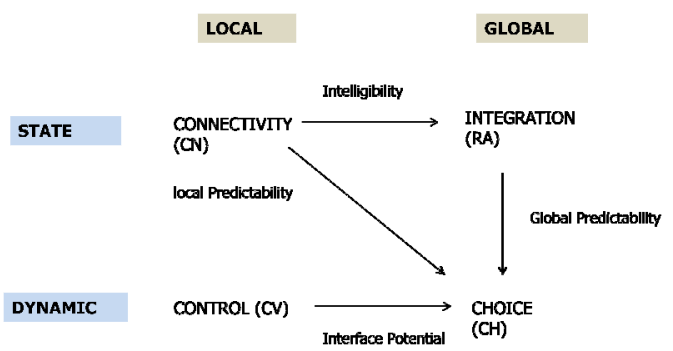

Fig. 2. Relationship between first and second order syntactic measures

The most important measure is Integration which is the relative depth or shallowness of any spatial system seen from any particular point within it. The integration values are the rank ordered from most integrated to the most segregated line. The set of most integrated streets are collectively known as 'integration core' whose nature, shape, size, coverage etc depends basically on the shape, connectedness and geometry of the urban system and its mode of growth. The method is also used to understand the structure locally of integrated lines $(R=3$ or 4$)$, by computing a more immediate measure giving a value for integration among the spaces up to three or four steps away from the root.

The second measure is Choice $(\mathrm{CH})$, which expresses the extent to which a particular space (axial line) figures as a choice on all shortest routes from all spaces to all other spaces in the system. Connectivity $(C N)$ is literally the number of immediate neighbors that are connected to a space. It is a local syntactic measure. The Control (CV) represents the amount of choice a space represents to its immediate neighbors as somewhere to go. The Global choice is a dynamic global measure of the 'flow' through a space. The second order measures even have sociological potential. The correlation between global integration and connectivity is considered to index the Intelligibility of the system which means the degree to which what we can see from the spaces that make up the system. It leads to a strong sense of reliability of the grid from local scale towards a larger context. Integration has now been found empirically to correlate well with observed patterns of space occupancy, use and movement in towns and cities in different parts of the world (Nilufar 1998).

In the syntactic analysis of Dhaka, the total structure seems well balanced with integrated parts at the physical center and segregated parts towards the periphery (Fig. 3). There is a distinct edge effect having all the peripheral areas segregated. The highest integrated line is Outer Circular Road. Most of the areas of old city in the southern side remain segregated to a degree. The open spaces are situated away from the global integration core but surrounded by highly integrated lines. Some of the open spaces are located across roads with highly busy vehicular traffic.

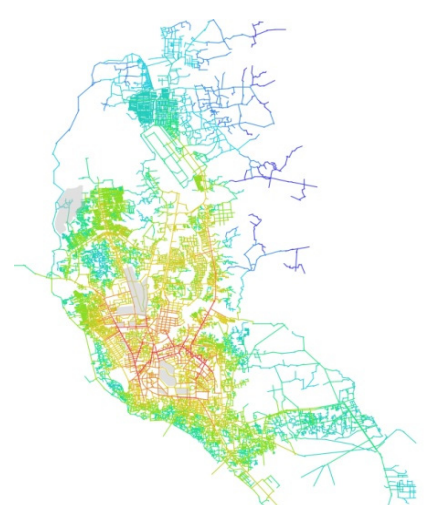

Fig. 3. Axial Map (Khan 2007) of Dhaka city with global integration $(R=n)$

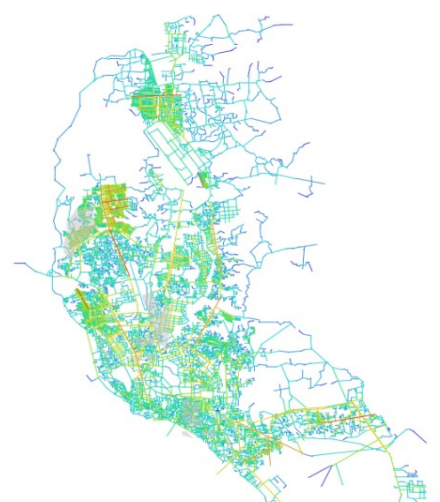

Fig. 4. Axial Map of Dhaka city with local integration $(\mathrm{R}=4)$

The local integration ( $\mathrm{R}=4$ analysis) core is a dispersed set of lines (Fig. 4). One feature of the local system is that each of the parts or localities in newer Dhaka (like Gulshan, Dhanmondi) has at least one locally integrated line. The correlation between global and local integration is reasonably good (0.474) (Fig. 5). At the same time the intelligibility of the city is low (0.184) (Fig. 6). But when the value of the access routes to open spaces are considered only the correlation value is good for both the cases (respectively $0.683,0.695$ ). The global integration range is similar for all the cases, but the local integration $(\mathrm{R}=4)$ and connectivity range markedly vary (Fig. 7-Fig. 9). 


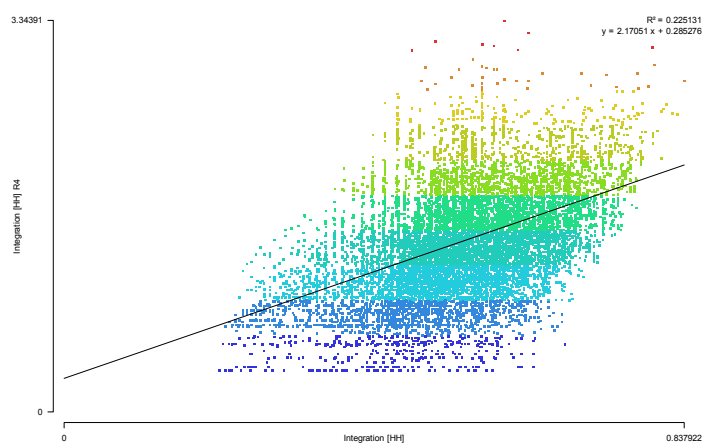

Fig. 5. Correlation between Global integration $(\mathrm{R}=\mathrm{n})$ and Local integration $(\mathrm{R}=4)$

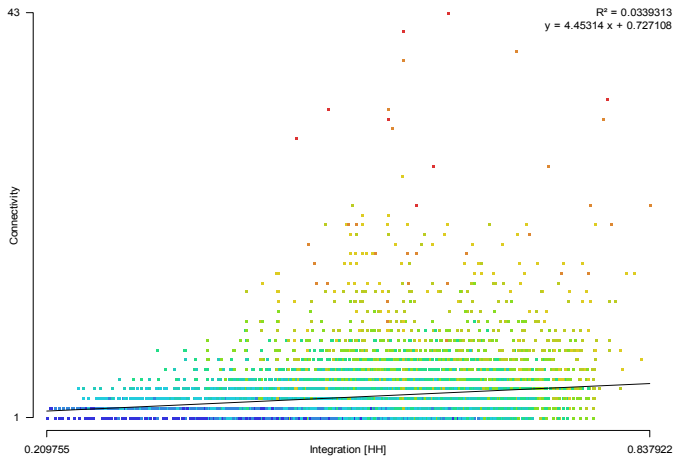

Fig. 6. Correlation between global integration $(\mathrm{R}=\mathrm{n})$ and Connectivity: intelligibility
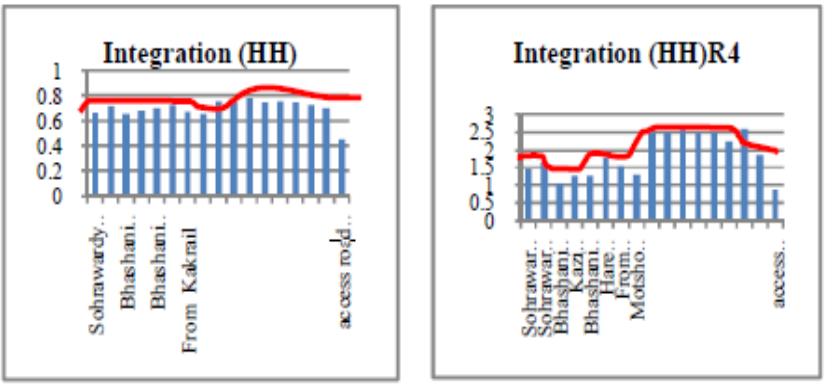

Fig. $7 \&$ 8. Graphs showing global and local integration

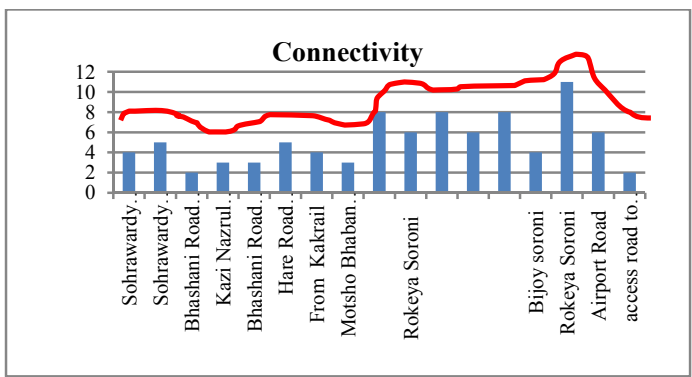

Fig. 9. Graph showing connectivity of the open spaces

The axial line integration analysis says something fundamental about the spatial integration of public green and open spaces. Integrated spaces will, according to the theory of natural movement (Hillier et al 1993), play a more central role in the urbanity. These spaces will not only be more frequently visited and used, they will also probably get better known because they are located in more legible places and at the same time within the people's daily movement patterns (Stahle, 2005).

The permeability of any system of public space depends on the number of alternative routes it offers from one point to another but these alternatives must be visible (Bentley, Alcock, Murrain, McGlynn, Smith, 1985:12). The entrance points are decided based on the choice value (global measure) and connectivity (local measure) of each link to achieve a balance between the accessibility at the city wide and local scale.

The integration values below 1- of the order of 0.4 to 0.6 indicate more segregation and while the value ending to and above 1 show strong integration. The global integration value of the access roads to Sohrawardy Udyan denotes that this is located at moderately integrated area. The main entrance of the park is from Kazi Nazrul Islam Avenue, the global integration value of which is highest among the access routes. The site is not physically or visually permeable from Bhashani Road. (Fig. 9)

TABLE IV: PUBLIC OPEN SPACES WITH THEIR CONNECTIVITY, CONTROL AND INTEGRATION VALUE

\begin{tabular}{|c|c|c|c|c|c|c|}
\hline Open Space & no & Access Roads & Connectivity & Control & Integration $(\mathrm{HH})$ & Integration $(\mathrm{HH}) \mathrm{R} 4$ \\
\hline \multirow{4}{*}{ 1.Sohrawardy Uddyan } & 1 & Sohrawardy Uddyan Road(Bangla Academy) & 4 & 1.033333 & 0.665882 & 1.453071 \\
\hline & 2 & Sohrawardy Uddyan Road(TSC) & 5 & 1.2 & 0.724404 & 1.664845 \\
\hline & 3 & Bhashani Road (Ramna Park) & 2 & 0.75 & 0.656466 & 1.06877 \\
\hline & 4 & $\begin{array}{l}\text { Kazi Nazrul Islam Avenue(Fine Arts } \\
\text { Institute) }\end{array}$ & 3 & 0.833333 & 0.675075 & 1.293798 \\
\hline \multirow{3}{*}{ 2.Ramna Park } & 5 & Bhashani Road (Shahbagh) & 3 & 1 & 0.704288 & 1.291875 \\
\hline & 7 & From Kakrail & 4 & 1.416667 & 0.67089 & 1.553238 \\
\hline & 8 & Motsho Bhaban Morh & 3 & 0.75 & 0.656086 & 1.3089 \\
\hline \multirow{3}{*}{ 3.Chandrima Udyan } & 9 & Crescent Lake Road & 8 & 2.122024 & 0.756935 & 2.498965 \\
\hline & 10 & Rokeya Soroni & 6 & 1.118687 & 0.749385 & 2.490898 \\
\hline & 18 & Mirpur Road & 16 & 3.70917 & 0.77432 & 2.88855 \\
\hline \multirow{4}{*}{$\begin{array}{l}\text { 4.North and South } \\
\text { Plaza of National } \\
\text { Assembly Building }\end{array}$} & 11 & $\begin{array}{l}\text { South Plaza of National Assembly Building- } \\
\text { Manik Mia Avenue }\end{array}$ & 8 & 2.939668 & 0.7813 & 2.629892 \\
\hline & 12 & $\begin{array}{l}\text { South Plaza of National Assembly Building- } \\
\text { Rokeya Soroni }\end{array}$ & 6 & 1.118687 & 0.749385 & 2.490898 \\
\hline & 13 & $\begin{array}{l}\text { North Plaza of National Assembly Building- } \\
\text { Crescent Lake Road }\end{array}$ & 8 & 2.122024 & 0.756935 & 2.498965 \\
\hline & 19 & Mirpur Road & 34 & 11.019 & 0.794357 & 3.11753 \\
\hline \multirow{3}{*}{$\begin{array}{l}\text { 5.National Parade } \\
\text { Square }\end{array}$} & 14 & Bijoy Soroni & 4 & 0.601923 & 0.752173 & 2.242486 \\
\hline & 15 & Rokeya Soroni & 11 & 3.767308 & 0.728578 & 2.607944 \\
\hline & 16 & Airport Road & 6 & 1.97619 & 0.708546 & 1.858436 \\
\hline 6.Botanical Garden & 17 & Access road to Botanical Garden & 2 & 0.8333333 & 0.448223 & 0.8717595 \\
\hline
\end{tabular}


The Ramna Park is located at a moderately integrated area. The most integrated road is the Hare Road (the local integration value of which is also higher) which feeds the residential area of Baily road. It is observed that the residents of this area use this park for morning walk and exercise. There is no entrance point from Kakrail which makes this area physically inaccessible to the people moving on this road. (Fig. 10)

Both the local and global integration value of Chandrima Uddyan is reasonably high. The site is only accessible from Crescent Road and the entrance points are quite away from the Mirpur Road and Rokeya Soroni. The entrance points are not also visible which in turn affects the use of this park. (Fig. 11)
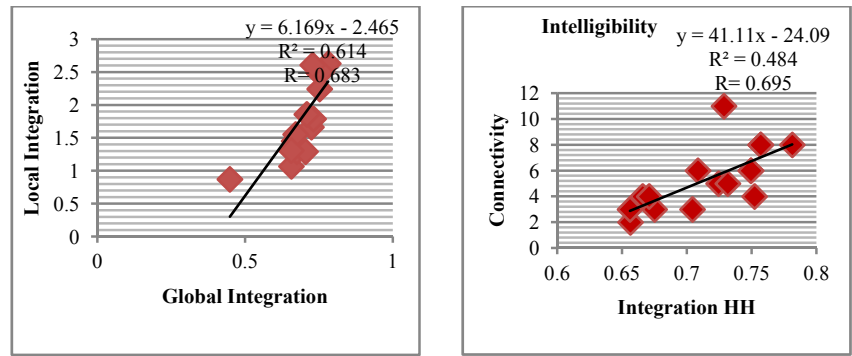

Fig. $10 \& 11$. Correlation considering only the values of the access road of the open spaces

TABLE V: MAX, Min AND MEAN CONNECTIVITY, CONTROL AND INTEGRATION VALUE OF THE CITY

\begin{tabular}{|l|l|l|l|l|}
\hline & Connectivity & Control & $\begin{array}{l}\text { Integration } \\
(\mathrm{HH})\end{array}$ & $\begin{array}{l}\text { Integration } \\
(\mathrm{HH}) \mathrm{R} 4\end{array}$ \\
\hline Minimum & 1 & 0.0263158 & 0.209755 & 0.351994 \\
\hline $\begin{array}{l}\text { Average / } \\
\text { Mean }\end{array}$ & 3.12943 & 1 & 0.539467 & 1.45619 \\
\hline Maximum & 43 & 15.1177 & 0.837922 & 3.34391 \\
\hline
\end{tabular}

Once the south plaza of the National Assembly Building remained occupied with people coming for roaming around, walking and doing exercise. But now the entry is restricted whereas it is located beside highly integrated access roads both locally and globally. (Fig. 12)

The National Parade Square is an underutilized Government area but it is located near the integration core of the city, near the roads having high connectivity and integration value. Both the global and local integration value of these roads are quite high which refers to the higher accessibility of this huge open area. (Fig. 13)

The local and global integration value and as well as the connectivity of Botanical garden is poor. It is located at an isolated area far from the integration core. This garden is approached from only one road. (Fig. 14)

Once the south plaza of the National Assembly Building remained occupied with people coming for roaming around, walking and doing exercise. But now the entry is restricted whereas it is located beside highly integrated access roads both locally and globally. (Fig .15)

The National Parade Square is an underutilized Government area but it is located near the integration core of the city, near the roads having high connectivity and integration value. Both the global and local integration value of these roads are quite high which refers to the higher accessibility of this huge open area. (Fig. 16)

The local and global integration value and as well as the connectivity of Botanical garden is poor. It is located at an isolated area far from the integration core. This garden is approached from only one road. (Fig. 17)

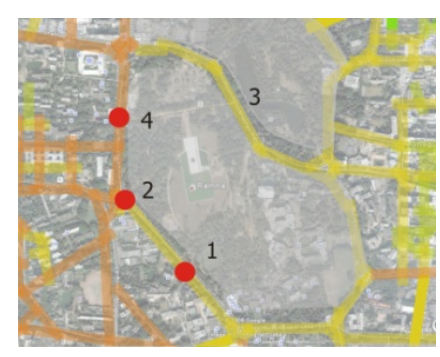

Fig. 12. Sohrawardy Uddyan with superimposed axial map $\mathrm{R}=\mathrm{n}$

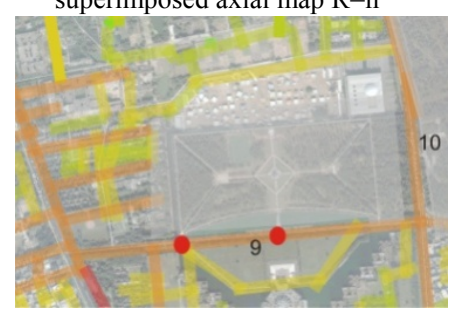

Fig. 14. ChandrimaUddyan

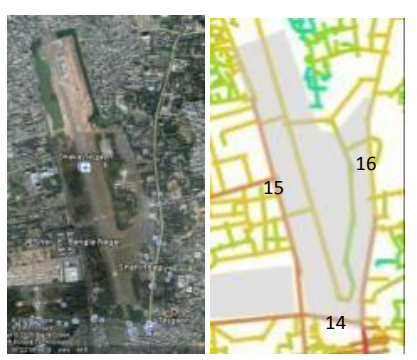

Fig. 16. National Parade Square

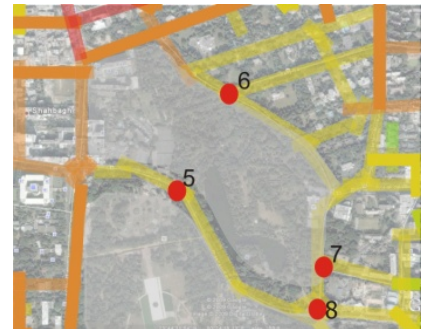

Fig. 13. Ramna Park

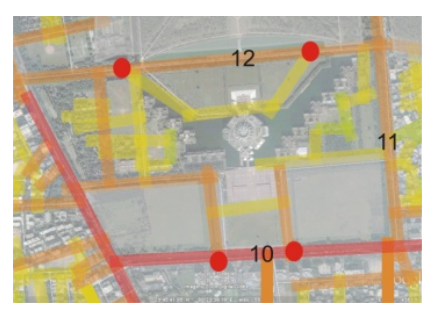

Fig. 15. North and South Plaza of National Assembly Building

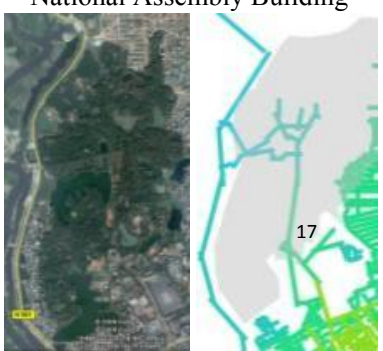

Fig. 17. Botanical Garden

\section{IMPLEMENTATION STRATEGIES FOR DHAKA CITY}

From the above analysis and discussion some strategies may be proposed for Dhaka City:

The global integration map of Dhaka city shows that the large scale parks like Ramna Park, Sohrawardy Udyan, Chandrima Udyan are located in highly integrated i.e. globally accessible areas. These spaces are used for recreational purposes what they are meant for. The use of these parks can be augmented by making their accessibility better i.e. by providing entrances from other adjacent roads of these parks with proper parking facility.

The Botanical Garden which occupies a huge land area is neither locally nor globally connected with the city. If it would be located at an integrated area, it could be more potentially used as an open space. It is to be made integrated with the city grid by increasing its accessibility. Such a garden might have slightly different approach or entry.

As the North and South Plaza of the National Assembly Building has high degree of accessibility which had a great impact on its use when it was open to general people. Minimization of restriction to this large open space of Dhaka city will mitigate the lacking of breathing space of the city dwellers to some extent.

The National Parade Square is located at a highly integrated area of Dhaka city but it is not accessible by the common people for recreational or other purpose. If it is converted to Dhaka's central park as per POLICY SE/10, DMDP because of its central position in relation to present 
and future pattern of urbanization coupled with its high accessibility, it would be able to mitigate the city dwellers' need of open space to some extent.

Chandrima Udyan, the North and South Plaza of the National Assembly Building, the National Parade Square have high local integration value which means they can also work as neighborhood park for the daily activities of the local people. Steps might be taken to locate the entrance points at such position which might create balance between the accessibility at city and local level.

\section{CONCLUSION}

When the large scale open spaces are located at highly integrated areas, they are within people's daily movement network and used frequently. In the case of Dhaka Space Syntax identifies that five of the six large open spaces are well integrated with the city grid. Some of these spaces are also well integrated at local level. From our daily experience we see that Ramna Park, Sohrawardy Uddyan, Chandrima Uddyan are used by people frequently for recreational purposes. The use of these parks can be made better by taking a few steps like increasing access points and proper location of those points. Space Syntax helps us to analyze the accessibility of these open spaces which helps in such decision-making.

\section{ACKNOWLEDGMENT}

This study has been conducted as part of the author's M.Arch Course on Urban Morphology at Department of Architecture, Bangladesh University of Engineering and Technology (BUET), Dhaka.

\section{REFERENCES}

[1] F. Nilufar, "Urban life and Public Open Space in Dhaka," report submitted to Asiatic Society of Bangladesh, 1999.
[2] A. S. M. M. Nabi, "Study of Open Space in Dhaka City," dissertation presented to the Development Planning Unit, University College, London, 1978.

[3] M. Francis, Urban Open Spaces- Designing for User Needs, Island Press, 2003.

[4] B. Ian, A. Alan, M. Paul, M. Sue, and S. Graham, Responsive Environments, Taylor and Francis, 1985

[5] Dhaka Structure Plan, 1995, DMDP: Dhaka Metropolitan Development Plan (1995-2015), Dhaka, Government of Bangladesh, 1995, Dhaka

[6] B. Hillier, A. Penn, J. Hanson, T. Grajewski, and J. Xu, "Natural movement or configuration and attraction in urban pedestrian movement," Environment and Planning B: Planning and Design, 1993.

[7] A. Stahle, "Park Syntax- Measuring Open Space Accessibility and Smart Growth," short paper to the $5^{\text {th }}$ Space Syntax Symposium, 2005.

[8] M. Islam, A. Kawsar, and R. U. Ahmed, "Open Spaces in Dhaka City- A Study on use of Parks in Dhaka City Corporation Area," undergraduate thesis report submitted to URP Department, BUET, 2002.

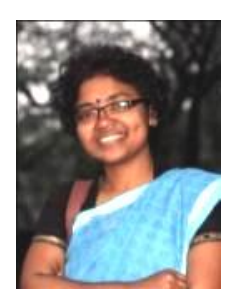

Matluba Khan was born in Bangladesh in 1984. She completed Bachelor of Architecture from the leading engineering University of Bangladesh- Bangladesh University of Engineering and Technology in 2009. She achieved her Master of Architecture from the same institute in 2012.

After her B.Arch she joined as a lecturer at Department of Architecture, Bangladesh University of Engineering and Technology. She has joined as an assistant professor in the same department in October 2012. Matluba has been working as an assistant architect in the Bureau of Research, Testing and Consultation (BRTC) in BUET since 2009. More than five peer reviewed papers are published in national and international seminar and conference proceedings. Matluba is interested in Built-Environment Studies particularly on children's learning environment focusing on behavioral issues. Her research experience includes a study on the outdoor learning environment of children at a primary school of Bangladesh which she completed in 2012 as a part of her M.Arch thesis dissertation. She is also involved in an international study on "IPEN Adolescent: International Study of Built Environments and Physical Activity" funded by National Institute of Health, USA.

Recently she has been awarded with Principal Career Development $\mathrm{PhD}$ Scholarship and Global Research Scholarship for Post Graduate Study in Landscape Architecture in the University of Edinburgh, UK from the Academic Session 2013-14. 